\title{
The influence of habitat structure, at different spatial scales, on the ecological distribution of macroalgal communities in streams
}

\author{
Rogério Antonio Krupek ${ }^{1}$ - Ciro César Zanini Branco ${ }^{2}$
}

Received: 18 May 2015/Accepted: 15 February 2016/Published online: 25 February 2016

(C) Botanical Society of Sao Paulo 2016

\begin{abstract}
Habitat heterogeneity influences the composition and structure of macroalgal communities in lotic environments. However, depending on the spatial scale, different environmental characteristics may exert more or less influence. This study aimed to evaluate, at different spatial scales of observation, the influences of local and regional environmental variables on ecological distribution of macroalgae in stream ecosystems. The field work was conducted during the months of June and July 2007 in streams of two river basins located in southern Brazil. The spatial scales used were drainage basin, shading, mesohabitat, and microhabitat. According to the results, there are few differences regarding abiotic variables between spatial scales, however, suggesting that sunlight and, consequently, the shading scale have a strong impact on the distribution pattern of stream macroalgae. The mesohabitat scale at the current velocity proved to be an important factor in structuring communities of macroalgae. Finally, microenvironmental factors (e.g., substrate, current velocity, and light availability) appear to exert their direct influence on the spatial distribution of stream macroalgae, generating particular features in each spatial scale of observation, although regional abiotic parameters (e.g.,
\end{abstract}

Rogério Antonio Krupek

rogeriokrupek@yahoo.com.br

1 Present Address: Departamento de Biologia, Universidade Estadual do Paraná, Campus de União da Vitória, Praça Coronel Amazonas, Caixa Postal 291, União da Vitória, PR 84600-000, Brazil

2 Present Address: Departamento de Ciências Biológicas, Universidade Estadual Paulista "Julio de Mesquita Filho", Av. Dom Antônio, 2100, Assis, SP 19806-900, Brazil temperature, $\mathrm{pH}$, and conductivity) should also be considered for the structural characterization of these organisms.

Keywords Heterogeneity $\cdot$ Macroalgae $\cdot$ Microhabitat . Stream

\section{Introduction}

The concern for the health of ecosystems and the interest in knowledge of biological diversity have generated a great demand for ecological information (Levin 1992; Meyer 1997), with the increased awareness that ecological relationships depend on the scale at which observations are made (Cooper et al. 1998). Physical processes, such as water flow and temperature, typically affect the distribution patterns of different organisms that live in streams and drainage basins (Townsend et al. 1983; Li et al. 1994; Wiley et al. 1997). Biotic interactions, including predation, competition, dispersal, and life history, can also create strong local effects (McAulife 1984; Kohler and Wiley 1997; Cooper et al. 1997).

A limited but growing number of studies suggest that physical habitat complexity (e.g., the number of distinct habitats or types of mosaics that compose an ecosystem) is one aspect of heterogeneity that has strong impact on the ecological processes that maintain ecosystem functioning (Pierce and Running, 1995; Gao et al. 2000; Cardinale et al. 2002). However, the precise significance of physical variability of habitats (e.g., spatial variation of physical properties within and between habitats) for ecosystem functioning remains largely unexplored (Cardinale et al. 2002). Benthic algae are a major primary producer in streams and rivers and provide a large part of the energy base that organizes production at higher trophic levels 
(Lambert 1996). However, our knowledge of the organization patterns of the benthic algae diversity in streams, including its control factors, are still insufficient (Biggs and Smith 2002).

Previous studies in lotic environments were aimed at understanding the relationship between the distribution pattern of macroalgal communities and the fluctuations of some typically regional environmental variables (e.g., dissolved oxygen-Necchi et al. 1991, 1994, 1995; electric conductivity-Branco and Necchi 1998; Biggs 1990; Necchi et al. 1994, 1995; water temperature-Sheath et al. 1989; pH-Entwisle 1990; Sheath et al. 1989). Recent studies (Branco et al. 2009; Krupek et al. 2007) have found that the particular characteristics of each lotic environment are the main factors responsible for the distribution patterns and the formation of a typical macroalgae community on a local scale. These results clearly indicate that small-scale spatial heterogeneity would exert a strong influence on the diversity and abundance of macroalgal communities of lotic environments.

Considering the scarcity of studies investigating the real importance of habitat heterogeneity on the structure and dynamics of stream macroalgal communities at local and regional scales, this study was proposed with the aim of clarifying the following questions: (1) considering two different drainage basins, what is the real importance of regional characteristics in determining the flora and distribution of stream macroalgal communities? (2) within the same drainage basin, are the composition and distribution of stream macroalgal communities more strongly related to particular combinations of factors on local scales (mesoand microenvironmental) than those of the basin itself (regional scale)?

\section{Materials and methods}

\section{Study area}

The river basin of Pedras river $\left(25^{\circ} 13^{\prime}-25^{\circ} 26^{\prime} \mathrm{S}\right.$ and $\left.51^{\circ} 13^{\prime}-51^{\circ} 28^{\prime} \mathrm{W} ; 330 \mathrm{~km}^{2}\right)$ and Marrecas river $\left(25^{\circ} 54^{\prime}-\right.$ $26^{\circ} 21^{\prime} \mathrm{S}$ and $52^{\circ} 54^{\prime}-53^{\circ} 17^{\prime} \mathrm{W} ; 765 \mathrm{~km}^{2}$ ) are located in the south-central region of the Paraná state, southern Brazil (Fig. 1).

This river basin was developed in reverse escarpment known as Serra da Esperança, being sculpted in the underside of a tholeitic basalt of the Serra Geral Formation, defined by rocks of intermediate-basic nature (Maack 2002). The Basin of Pedras river is entirely located in the city of Guarapuava with its rivers and tributaries flowing into the great drainage basin of the Jordão river. The Basin of Marrecas river is located mostly in Guarapuava, although part of it is in the City of Turvo. Their rivers and

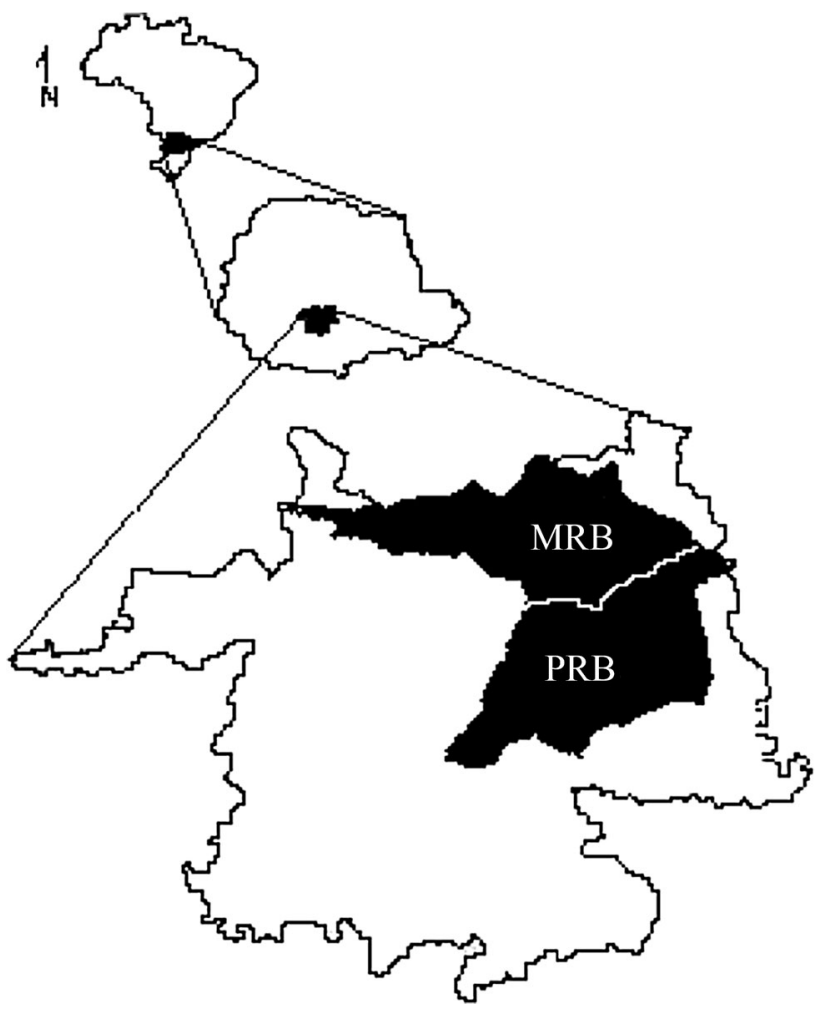

Fig. 1 General location of Pedras river basin (PRB) and Marrecas river basin (MRB) in Guarapuava, south-central region of the Paraná state, southern Brazil

streams flow into the large Ivaí river basin. These two drainage basins are located very close to one another (neighboring basins) in the same geographical area, and, thus, under similar climate conditions.

The regional climate is classified as wet subtropical mesothermic - without dry season, with cool summers and moderate winters. The annual average temperature is around $16-17.5^{\circ} \mathrm{C}$. Rain is well distributed throughout the year, with average annual rainfall being around $1960 \mathrm{~mm}$. The surrounding vegetation is basically constituted by Araucaria Forest. The forest areas are characterized by arboreal formations, mainly in the primary and secondary stages of forest regeneration, as well as shrub formations, usually composed of native species. Also, reforestation/forestation covering, mainly Pinus sp. (exotic species) and erva-mate (Ilex paraguariensis-native species) is observed.

\section{Experimental design}

The study considered the following spatial scales of sampling, which were regarded as important in the development of spatial distribution patterns in macroalgal communities in stream ecosystems: (1) Regional scale (=drainage basin); (2) Local scale (a) mesohabitat = pools, 
with current velocity between 0 and $11.8 \mathrm{~cm} / \mathrm{s}$ and riffles at current velocity of greater than $19.4 \mathrm{~cm} / \mathrm{s}$; (b) Microhabitat (sampling unit) $=$ pre-defined area $($ a circle of $20 \mathrm{~cm}$ diameter $=0.05 \mathrm{~m}^{2}$ ) in which all biotic variables (richness and abundance of species) and environmental (irradiance, water velocity, depth, and type of substrate) were taken. In addition, the effect of shading was investigated, so that segments of shaded and open streams were evaluated in each drainage basin. Shaded environment is considered an environment with visible marginal vegetation that prevents sunlight from reaching the water of the stream. An open environment is not surrounded by riparian vegetation, allowing greater incidence of sunlight and a greater amount of solar energy captured. Considering this, the sample design consider the variations in different scales on the extent, maintaining the same sample units in size.

Sampling of macroalgal communities and environmental variables was performed in June-July 2007 in 20 selected streams: 10 streams located in the Pedras River Basin, and 10 streams located in the Marrecas River Basin. In each basin, of the ten selected streams, five open streams (no marginal vegetation) and five shaded streams (with evident macroalgae growth) were selected, according to DeNicola et al. 1992. Each stream analyzed was then subdivided into two types of mesohabitats: pools and riffles. In turn, within each mesohabitat, microhabitat analyzes were performed.

Each sample point consisted of a segment of the stream ranging from 10 to $20 \mathrm{~m}$ in length, where field investigations were conducted using the technique of square (Necchi et al. 1995) (Fig. 2). At each sampling unit, the presence or the absence of each species of macroalgae was observed, and their respective abundance in terms of percent coverage was estimated by visual examination. The observations of richness and abundance of communities in each sample unit were assisted by underwater observation, and representative specimens of each species were collected for laboratory analysis.

The sampling units were positioned in areas with evident macroalgae growth, both mesohabitat riffles and pools. Where possible, 20 sampling units were used for each stream, 10 for each mesohabitat studied. An equal number of squares devoid of macroalgae (designated control) were randomly sampled for comparison with microhabitat characteristics of environments containing macroalgae.

\section{Environmental analysis}

In each sampling unit, the variables, current velocity and irradiance, were measured as close as possible to substrate using, respectively, a digital current meter, SWOFFER 2100 , and a digital quantometer, Li-Cor 189, with spherical
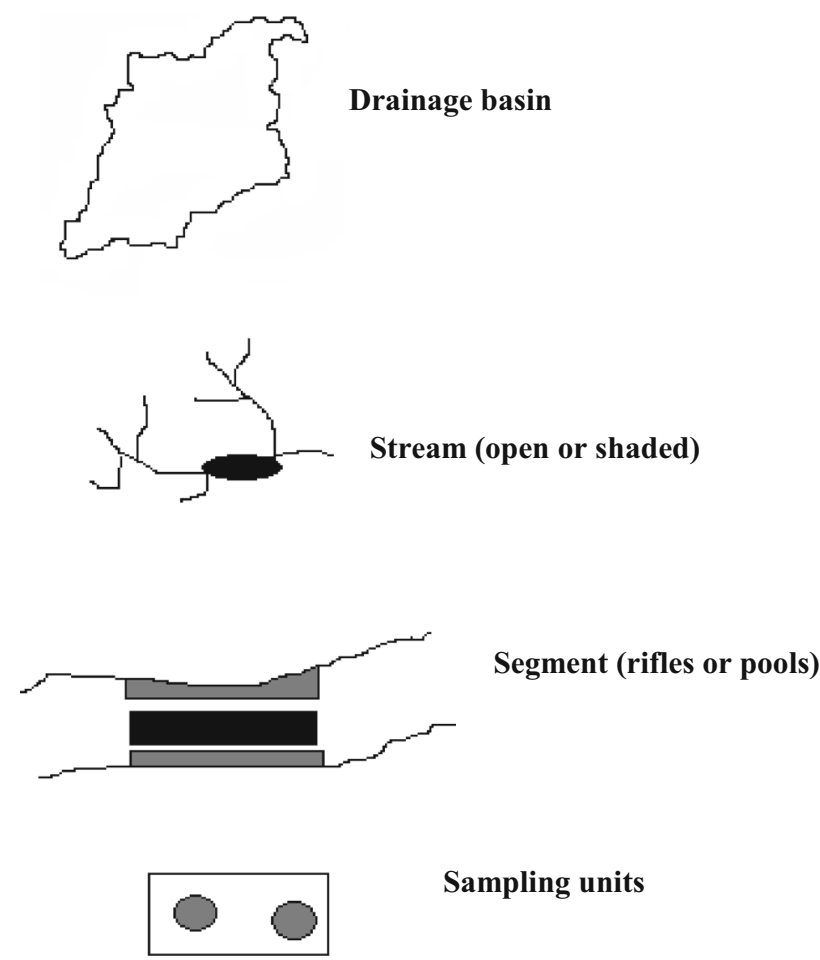

Fig. 2 Design of a sample of drainage basin where the other units or spatial scales were selected: 10 streams, with five open and five shaded, one segment at a stream, the same being subdivided into mesohabitat pools and riffles and 20 sample units per mesohabitat, 10 with the presence of macroalgae and 10 with the absence of macroalgae (control)

quantum sensor, Li-193SA. The depth was measured in each sample unit with a ruler. The identification of different types of substrate followed on the system based in classes of size proposed for Gordon et al. (1992). To quantify the heterogeneity of the substrate, two metric measurements were used: (i) richness of substrate types, and (ii) diversity of the substrate, which was obtained with the Shannon-Wiener diversity index, using the number of substrate types and the percent cover value for each substrate.

For the purposes of general characterization of environments, the following physical and chemical parameters of the streams were measured: water temperature, turbidity, specific conductivity, $\mathrm{pH}$, and dissolved oxygen. All variables were measured in the field, from a sample of water and with the aid of water-quality analyzer equipped with a multiparameter probe, HORIBA U-10.

\section{Taxonomic analysis}

The materials preserved in the field were transported to the laboratory and observed using a Carl Zeiss binocular microscope-Jenamed 2. Microscopic measurements were performed with the aid of an ocular micrometer, and for 
each sample, 10 random measurements were taken from the diagnosed structures. The macroalgae were identified to species level (or infra-specific), wherever possible. The classification of species according to the divisions followed the system used by Van De Hoek et al. (1995), except for Cynobacteria, which was classified according to Komárek and Anagnostidis (1986, 1989), Anagnostidis and Komárek (1988).

\section{Data analysis}

\section{Spatial scales of variation of community structure}

Community structure was described by the following variables: (i) richness of macroalgal community (number of taxa per sample); (ii) abundance of macroalgal community (percent cover in each sample unit); (iii) diversity index of Shannon-Wiener $H^{\prime}=\sum\left(p_{\mathrm{i}}\right)\left(\log p_{\mathrm{i}}\right)$, where $p_{\mathrm{i}}$ is the percentage cover of the species in section; (iv) Simpson dominance index: $C=\sum\left(X_{\mathrm{i}} / X_{\mathrm{o}}\right)^{2}$, where $X_{\mathrm{j}}$ is the abundance of each species in the sample, and $X_{\mathrm{o}}$ is the total abundance of species of macroalgae in the sample unit; (v) Evenness or Equity: $J=H^{\prime} / H_{\max }^{\prime}$ where $H^{\prime}$ is the Shannon-Wiener index and $H_{\max }^{\prime}=\log S H_{\max }^{\prime}=\log S$, where $S$ is the number of species sampled; (vi) Jaccard similarity index $\left(S_{\mathrm{j}}\right): S_{\mathrm{j}}=a / a+b+c$, where $a$ is the number of common species in the environments $\mathrm{A}$ and $\mathrm{B} ; b$ is the number of species exclusive of the environment $\mathrm{A}$; and $c$ is the number of species exclusive of the environment $\mathrm{B}$; and $\mathrm{A}$ and $\mathrm{B}$ are the spatial scales studied.

Variations in community structure (richness, abundance, $\left.H^{\prime}, C, J\right)$ at different spatial scales were assessed by Factorial Analysis of Variance (ANOVA-Type III). This analysis divided the entire variation into components that represent variations at different spatial scales (Zar 1999). The hierarchical independent variables used in this ANOVA were the spatial scales drainage basin, shading (open or shaded), and mesohabitat (pools or riffles). For each biotic variable, the differences in each individual spatial scale and possible interactions between them were evaluated. For richness and abundance (percent cover), the logarithmic transformation of data was used because of the significant variations within the spatial scales, in order to normalize distributions and homogenize variances.

Since the samples with algal populations have not always achieved ten units for each mesohabitat and shading (especially for pools and shaded environments, where the presence of macroalgae was less frequent), curve rarefaction using a Monte Carlo permutation method was used to homogenize data richness and, thus, avoid possible influences due to differences in sampling efforts. This procedure was not used for regional scale (drainage basin), since the same number of samples was used for the basins of the Pedras river and Marrecas river. Rarefaction procedures were performed using the simulation program Ecosim 5 (Gotelli and Entsminger 2000).

\section{Relationship between community structure and environmental variables}

In order to assess the possible influence of physical and chemical parameters of water on the structure of macroalgal communities, the statistical tests described below were performed: initially, the sampling sites $(n=20)$ were ordered based on all environmental variables using principal component analysis (PCA). Then the PCA axes were used as variables, with Student's $t$ test performed to detect possible differences between streams of the two drainage basins. Only axis $1(P<0.001)$ was significant: its most important variables were temperature (0.536), oxygen saturation $(-0.558)$ and $\mathrm{pH}(0.507)$. Subsequently, these variables were used as independent variables in a multiple linear regression analysis to assess their combined impact (together) on the macroalgal community structure (richness, abundance, $H^{\prime}, C, J$ ). These analyzes were performed using the programs PC-ORD 4.0 (McCune and Mefford 1999) and Statistica 5.0 (Statisoft Incorporation).

The local variation of microenvironmental variables (depth, current velocity, irradiance, richness, and diversity of substrate), at different spatial scales, was examined with Factorial Analysis of Variance (ANOVA-Type III). The hierarchical independent variables used were spatial scales (drainage basin, shading, and mesohabitat). Also, possible differences between the sampling units "with algae" and "with no algae" (control) were examined in different microhabitats within the mesohabitats. Therefore, the canonical variables analysis (CVA) was used, based on a matrix of microenvironmental data for the sample units ("with algae" and "no algae") during the sampling period.

The relationships between the structure and the composition of communities and all microenvironmental variables at different spatial scales were examined by Multiple Linear Regression Analysis. However, at first all variables were analyzed by correlation coefficient Pearson's $r$, to verify whether they had co-variation or collinearity. Significant correlations between irradiance and depth were obtained $(r=-0.421, P<0.01)$ and between richness and $H^{\prime}$ of the substrate $(r=0.716, P<0.001)$. Since irradiance was considered a key factor in the development of communities of stream macroalgae, it was selected together with current velocity and $H^{\prime}$ substrate for use in Multiple Linear Regression Analysis, while the variables of depth and richness of the substrate that showed strong collinearity were discarded. 


\section{Results}

\section{Analysis of macroalgal communities}

A total of 29 taxa (23 species, 1 genus, and 5 vegetative groups) of macroalgae were identified in lotic environments of the two studied drainage basins. Of these, 12 belong to the division Chlorophyta, 11 to Cyanobacteria, 4 to Heterokontophyta, and 2 to Rhodophyta (Table 1). In lotic waters of Pedras River Basin, a total of 20 species were identified, and in rivers and streams of the Marrecas River Basin a total of 19 species were found (Table 1). The total number of species, 10 (34.5\% of total species) occurred exclusively in the rivers and streams of the Pedras River Basin and 9 (31\% of total) exclusively in the rivers and streams of the Marrecas River Basin. Ten (34.5\% of total) species were common to both drainage basins (Table 1).

In relation to shading (Table 1), eight species (40\%) were exclusive of open environment and eight (40\%) of shaded environment, with only four $(20 \%)$ common to both types of marginal vegetation cover investigated in streams from the Pedras River Basin. In turn, in the Marrecas River Basin, 12 species $(63.2 \%)$ were found only in open environments and four (21\%) only in shaded environments. Only three species $(15.8 \%)$ were common to both types of marginal vegetation cover.

In the Pedras River Basin, 10 species occurred exclusively in mesohabitat riffles, three exclusively in mesohabitat pools, and seven were common to both mesohabitats (Table 1). In the streams of the Marrecas River Basin, four species were exclusive to mesohabitat riffles, while seven species were exclusive to mesohabitat pools and eight were common to both mesohabitats (Table 1).

The similarity values in the floristic composition of communities, indicated by the Jaccard coefficient $\left(S_{\mathrm{j}}\right)$ showed the following results: (a) drainage basins: 0.41 (=41\%); (b) Pedras River Basin: (i) open environment $\times$ shaded: $0.21(=21 \%)$; (ii) pools $\times$ riffles: 0.35 $(=35 \%)$; (c) Marrecas River Basin: (i) open environment $\times$ shaded: $0.22(=22 \%)$; (ii) pools $\times$ riffles: 0.31 $(=31 \%)$.

\section{Spatial scales of variation of community structure}

The mean and standard deviation for the variables that describe the structure of macroalgal communities (richness, abundance, $H^{\prime}, C$, and $J$ ), for each of the evaluated spatial scales are presented in Table 2.

Significant differences were found only for richness and abundance (percent cover) of species, so that both varied significantly only in the scale of shading (Table 3 ). The open habitats had higher species richness and abundance that shaded environments (Table 2).

When richness was standardized by rarefaction, removing the effect of sampling effort, richness again differed in scale shading, confirming the results of the ANOVA (Fig. 3).

\section{Relationship between community descriptors and environmental variables}

PCA (Fig. 4) showed a clear separation of environmental characteristics between the two drainage basins studied with respect to the first axis. This accounted for $46.2 \%$ of the total ordination explained (Table 4). A distinction between the Pedras River Basin and Marrecas River Basin was confirmed by $t$ test $(t=-5.143, P<0.001)$. The environmental variables responsible for this distinction were temperature, oxygen saturation and $\mathrm{pH}$ according to the PCA loadings (Table 4). Other axes (2 and 3) showed no differences (eigenvalues smaller than 2.0) with respect to the ordering of the sampling points of the two basins (Fig. 4; Table 4).

Although these three variables influence the ordering of sampling points between the two basins, they did not affect the structure of macroalgal communities assessed by multiple regression analysis.

The microenvironmental variables ranged widely within the spatial scales sampled, but showed few significant differences. Only current velocity showed significant variation in scale mesohabitat $(F=137.7, P<0.001)$ and irradiance in the scale shading $(F=83.13, P<0.001)$.

Differences in microenvironmental variables between sampling units with macroalgae and without macroalgae ("control") within mesohabitats pools and riffles were rare despite the large variation observed for all variables. Canonical variable analysis (CVA, Fig. 5) showed highly significant differences $(F=10.13, P<0.001)$. This analysis showed that there were no significant differences for both sampling units with algae as for the controls (Fig. 5) in mesohabitats pools and riffles. The variable that most contributed to this differentiation was current velocity ( $P=0.000$, corresponding to axis 1$)$. When only sample units with or without algae were considered, significant differences were observed only in mesohabitat riffles (Fig. 5). The variable that most contributed to this differentiation was depth (0.003, corresponding to axis 2). Axes 1 and 2 accounted for $92 \%$ of the cumulative percentage.

Multiple Regression Analysis showed that the different variables that describe the community structure were influenced by microenvironmental variables at the different spatial scales examined (Table 5). At the spatial scale of mesohabitat riffles, there was a strong relationship of 
Table 1 List of species in lotic environments of Rio das Pedras basin (PRB) and Rio Marrecas basin (MRB)

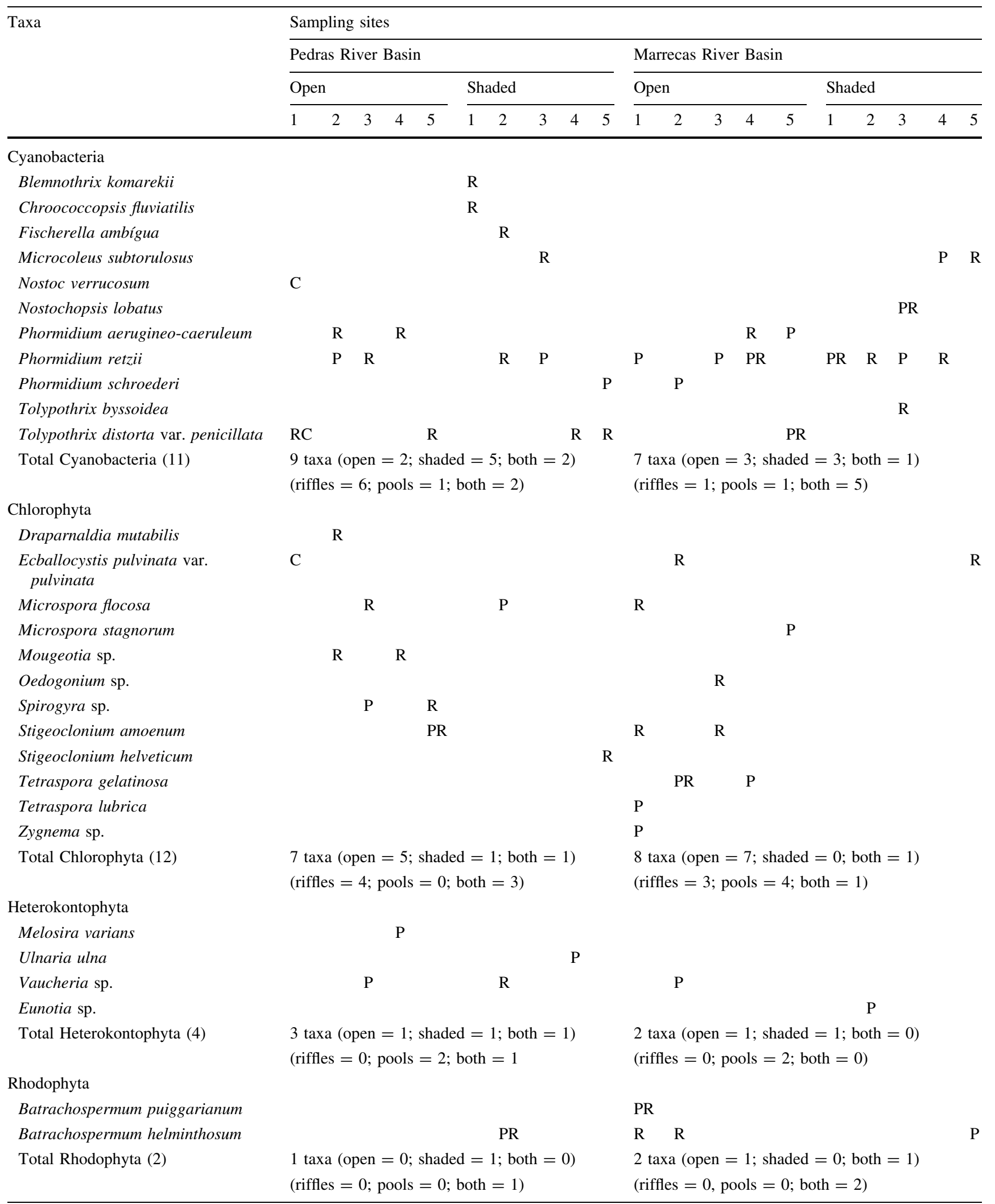

$P$ Pools, $R$ riffles 
Table 2 Mean values and standard deviation of the community structure (richness, abundance (percent cover), $H^{\prime}$, $C$, and $J$ ) for each of the spatial scales examined

\begin{tabular}{lrrlll}
\hline & \multicolumn{1}{c}{ Richness } & Abundance & \multicolumn{1}{l}{$H^{\prime}$} & \multicolumn{1}{l}{ C } \\
\hline Pedras river & & & & & \\
Drainage basin & $3 \pm 0.66$ & $14.1 \pm 17.2$ & $0.30 \pm 0.09$ & $0.52 \pm 0.14$ & $0.66 \pm 0.18$ \\
Open environment & $3.2 \pm 0.44$ & $23.9 \pm 20.4$ & $0.31 \pm 0.06$ & $0.47 \pm 0.14$ & $0.63 \pm 0.15$ \\
Shaded environment & $2.8 \pm 0.83$ & $4.28 \pm 3.55$ & $0.28 \pm 0.12$ & $0.55 \pm 0.14$ & $0.68 \pm 0.22$ \\
Mesohabitat riffles & $2.3 \pm 0.67$ & $13.3 \pm 16.6$ & $0.19 \pm 0.12$ & $0.70 \pm 0.19$ & $0.48 \pm 0.30$ \\
Mesohabitat pools & $1.1 \pm 0.56$ & $10.6 \pm 15.9$ & $0.02 \pm 0.05$ & $0.86 \pm 0.31$ & $0.08 \pm 0.19$ \\
Marrecas river & & & & & \\
Drainage basin & $3.2 \pm 1.4$ & $13.1 \pm 13.6$ & $0.29 \pm 0.20$ & $0.63 \pm 0.24$ & $0.55 \pm 0.30$ \\
Open environment & $4 \pm 1.5$ & $14.1 \pm 18.4$ & $0.39 \pm 0.19$ & $0.53 \pm 0.23$ & $0.65 \pm 0.20$ \\
Shaded environment & $2.4 \pm 0.89$ & $12.1 \pm 8.7$ & $0.19 \pm 0.17$ & $0.72 \pm 0.24$ & $0.44 \pm 0.27$ \\
Mesohabitat rifles & $1.6 \pm 0.84$ & $14.3 \pm 23.4$ & $0.09 \pm 0.14$ & $0.85 \pm 0.23$ & $0.23 \pm 0.87$ \\
Mesohabitat pools & $2 \pm 1.24$ & $8.2 \pm 12.2$ & $0.13 \pm 0.14$ & $0.76 \pm 0.24$ & $0.38 \pm 0.43$ \\
\hline
\end{tabular}

Table 3 Summary of ANOVA showing the variation in the structure of macroalgal communities at different spatial scales evaluated

\begin{tabular}{lll}
\hline Spatial scale & $F$ & $\boldsymbol{P}$ \\
\hline Species richness & & \\
Drainage basin & 0.163 & 0.688 \\
Open/shaded & 5.680 & $\mathbf{0 . 0 2 3}$ \\
Pools/riffles & 2.612 & 0.115 \\
Abundance & & \\
Drainage basin & 0.264 & 0.898 \\
Open/shaded & 9.695 & $\mathbf{0 . 0 2 9}$ \\
Pools/riffles & 0.255 & 0.663 \\
$H^{\prime}$ & & \\
Drainage basin & 0.020 & 0.887 \\
Open/shaded & 1.158 & 0.289 \\
Pools/riffles & 2.543 & 0.120 \\
Dominance $(C)$ & & \\
Drainage basin & 0.104 & 0.749 \\
Open/shaded & 0.095 & 0.758 \\
Pools/riffles & 0.192 & 0.663 \\
Equity $(J)$ & & 0.937 \\
Drainage basin & 0.006 & \\
Open/shaded & 0.341 & 1.725 \\
Pools/riffles & & \\
\hline
\end{tabular}

Values in bold represent statistically significant differences

microenvironmental variables with all biotic variables. However, at other scales the relationships were less marked and sparse (Table 5). Only abundance was related to variables in scale drainage basin and species richness at scales of drainage basin and mesohabitat pools (Table 5). Scales related to shading (open and shaded environment) biotic variables showed no relationship with the microenvironmental variables (Table 5).

\section{Discussion}

The overall characteristics of macroalgal communities found in the two drainage basins are those typically described for this group of algae occurring in lotic environments (e.g., Borges and Necchi 2006; Branco et al. 2009; Branco and Necchi 1996; Krupek et al. 2007) namely: (i) extremely low number of species compared with other algal groups (e.g., periphyton or phytoplankton); (ii) species of common occurrence (cosmopolitan) and previously reported in most studies conducted in other Brazilian and world regions; (iii) large number of species (55.2 \% in this study) restricted to a single stream and few species with wide distribution (in this study only $6.9 \%$ of the species were present in more than three streams); (iv) values of abundance (percentage cover) extremely low, and (v) species occupying a small portion of the resources offered by the environment (patchy distribution). According to Krupek et al. (2007) and Branco et al. (2009), these characteristics are mainly due to local variations in the features of each segment of lotic reviews. However, the authors do not rule out the possible influence of regional factors on macroalgal communities.

Lotic environments present rapid and wide fluctuations under environmental conditions that are tolerated by few species (Borges and Necchi 2006; Sheath et al. 1986, 1989; Branco and Necchi 1996, 1998). The role of major events (or macroscale events) and the repetition of small disturbances can result in permanent immaturity of the macroalgae communities occurring in this type of environment and, consequently, overall low biomass (Resh et al. 1998; Biggs and Close 1989). Since the region where the studies were conducted have high rates of annual rainfall, which are well distributed throughout the year (Krupek et al. 2007), it is reasonable to believe that these 

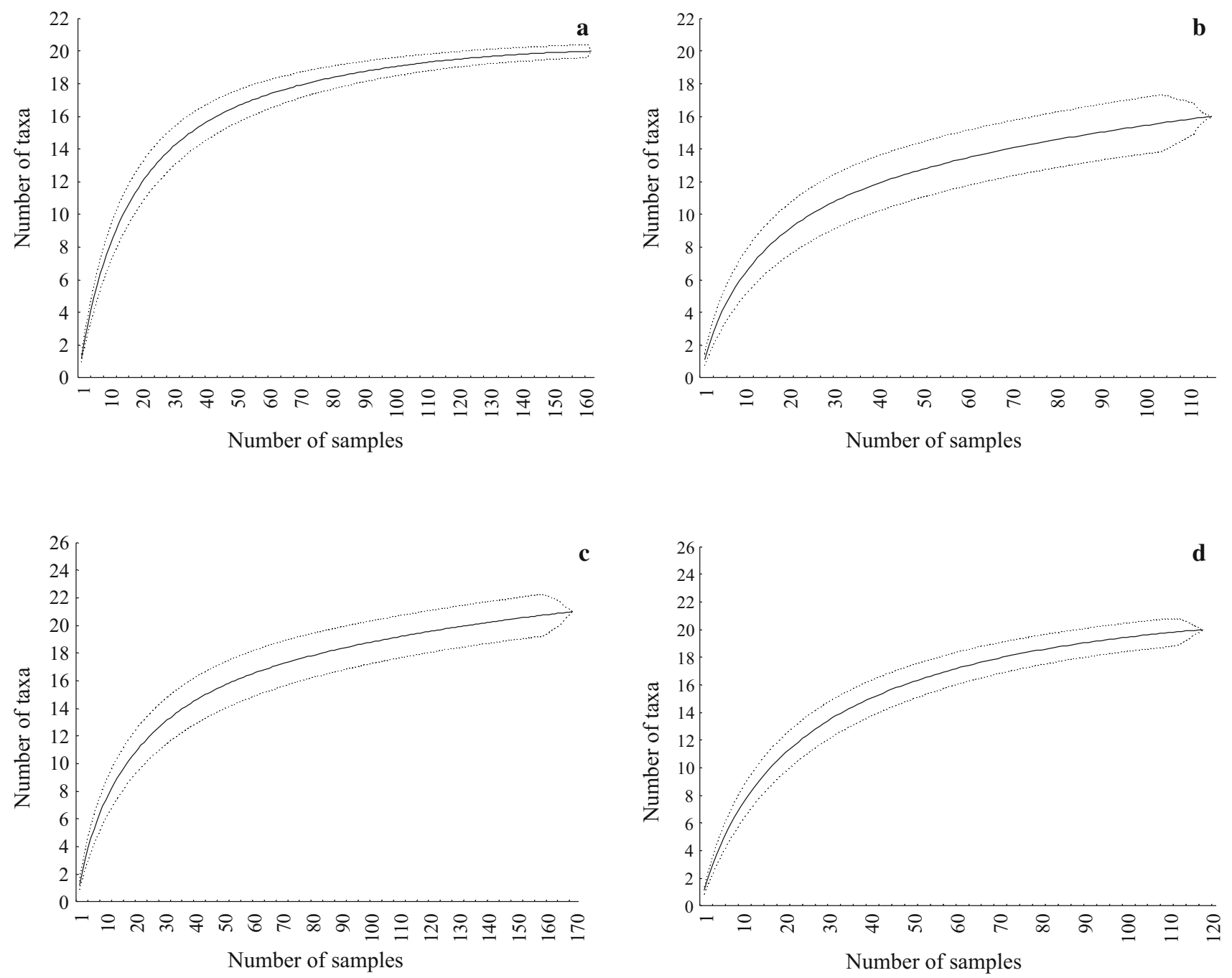

Fig. 3 Rarefaction curves of species richness of macroalgae at different spatial scales evaluated: a open environment, b shaded environment, c mesohabitat riffles, and $\mathbf{d}$ mesohabitat pools

precipitations may have some influence on the communities of macroalgae investigated. Biggs and Gerbeaux (1993) observed that features in macroscale as well as climate, geology, and land use would account for effects on the functioning of stream ecosystems in large areas (e.g., drainage basin), and features as well as regime nutrients, hydraulic condition, and shape of the bed, considered to be microscale would affect small areas (e.g., streams or stream sections). The same authors emphasize that many studies were developed from the analysis of a single segment by the river, supporting the theory that environmental differences and periphyton would be greater than those between rivers within the same basin. However, results that contrast with this prediction were obtained (Biggs and Gerbeaux 1993), leading the authors to conclude that local characteristics of lotic environments are very important both to the quantitative and community compositions. In the present study, we observed a great influence of microenvironmental variables (irradiance and current velocity), directly related to the local conditions of each environment. Considering the smaller scales used in this study, it is clear that microenvironmental conditions are very important in the spatial distribution of benthic macroalgae.

The variables that describe the structure of macroalgal communities showed little differences between the spatial scales studied. In general, there were no evident differences between spatial scales of drainage basin and mesohabitat for any of the biotic parameters. The main difference observed was the relatively high variation in macroalgal communities on the shading scale. Still, this was only obtained for the variables richness and abundance of species.

These results demonstrate the importance of sunlight as a determining factor in the spatial distribution of 


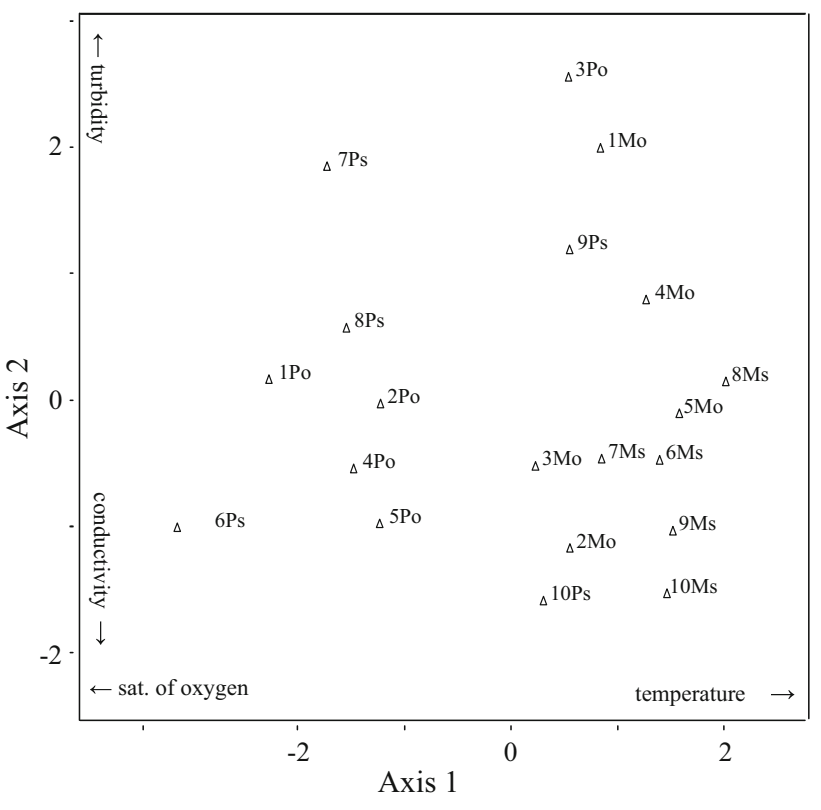

Fig. 4 Arrangement of sampling sites resulting from principal component analysis (PCA) based on all the physicochemical parameters

Table 4 Summary of PCA showing the eigenvalues for axes and eigenvectors for all regional environmental variables

\begin{tabular}{|c|c|c|c|c|}
\hline \multirow{2}{*}{$\begin{array}{l}\text { Axis } \\
1\end{array}$} & Eigenvalues & \multicolumn{2}{|c|}{$\%$ de Variance } & $\begin{array}{l}\% \text { de Variance } \\
\text { accumulated }\end{array}$ \\
\hline & 2.312 & & & 46.2 \\
\hline 2 & 1.335 & & & 72.9 \\
\hline 3 & 0.747 & & & 87.8 \\
\hline \multirow{2}{*}{\multicolumn{2}{|c|}{ Variables }} & \multicolumn{3}{|c|}{ Loadings } \\
\hline & & Axis 1 & Axis 2 & Axis 3 \\
\hline \multicolumn{2}{|c|}{ Temperature } & 0.536 & -0.108 & -0.528 \\
\hline \multicolumn{2}{|c|}{ Sat. of oxygen } & -0.558 & 0.167 & -0.302 \\
\hline \multicolumn{2}{|c|}{ Conductivity } & -0.235 & -0.688 & 0.491 \\
\hline \multicolumn{2}{|l|}{$\mathrm{pH}$} & 0.507 & -0.366 & 0.093 \\
\hline \multicolumn{2}{|c|}{ Turbidity } & 0.296 & 0.593 & 0.615 \\
\hline
\end{tabular}

Values in bold represent statistically significant differences

macroalgal communities in lotic environments. Both the richness and abundance were higher in open than in shaded streams, indicating that shading is a limiting factor of the development of stream macroalgae and perhaps for the assessed spatial scales, the one that best explains the structural differences in the spatial distribution of these organisms. Many studies have shown that the presence (and diversity and abundance) of macroalgae is higher in environments with greater light availability (Branco and Necchi 1996; Krupek et al. 2007; Branco et al. 2009; Necchi et al. 2000; Sherwood and Kido 2002).

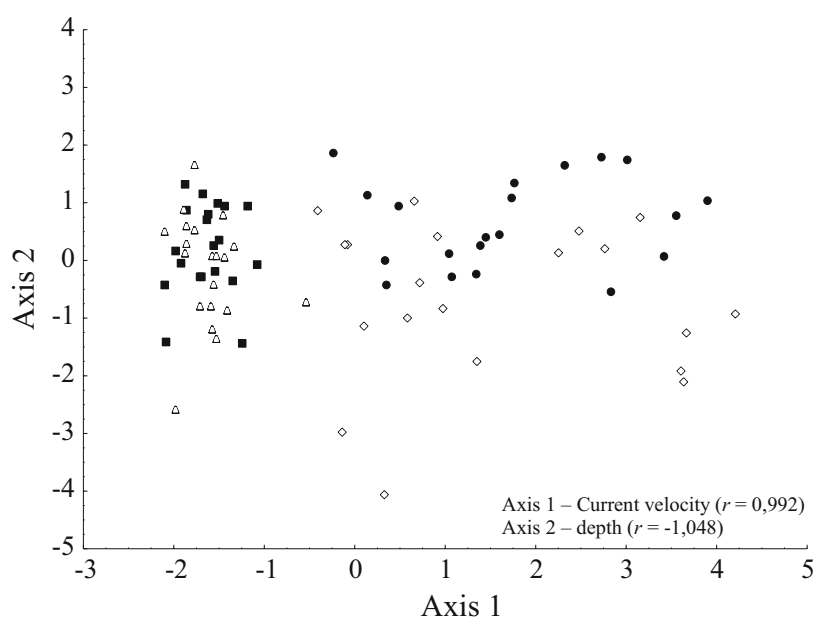

Fig. 5 Arrangement of sampling points resulting from canonical variables analysis (CVA) based on microenvironmental variables. filled circle Mesohabitat riffles with algae; diamond Mesohabitat riffles without algae; filled square Mesohabitat pools with algae; triangle Mesohabitat pools without algae

Regional environmental variables show differences between lotic environments when considering larger scales of distribution. In the present study, it was clear that there was the difference between the two drainage basins in relation to abiotic parameters evaluated. Despite the geographical proximity of the regions, different features were observed that may reflect a number of factors such as land use, geomorphology, and rainfall regime. However, despite these regional environmental differences between the two drainage basins, direct influences on the spatial distribution of macroalgal communities were not detected. Several previous studies have shown lack of correspondence between spatial distribution of macroalgal communities and environmental characteristics in the same region (e.g., Branco et al. 2009; Krupek et al. 2007) or in different regions (p. ex. Borges and Necchi 2006). Nevertheless, several studies related the spatial distribution of macroalgae to regional environmental variables (e.g., Biggs 1990; Branco and Necchi 1996; Entwisle 1990; Necchi et al. 2000, 1995; Sheath et al. 1986). Still, different segments of the same region may have different patterns of distribution to communities of macroalgae, which are generally influenced by local factors, specific of each segment (Borges and Necchi 2006; Krupek et al. 2007). Thus, it can be assumed that regional characteristics (e.g., $\mathrm{pH}$, conductivity, and temperature) have influence on the distribution of macroalgae, although only their combined action can drive or effectively determine the spatial distribution pattern.

The absence of microenvironmental or microscales in the different spatial scales of distribution and, yet the apparent similarity of the conditions in areas with and without macroalgae growth, lead us to pose the following 
Table 5 Summary of multiple regression analysis showing the influence of all variables microenvironmental measures on each variable of community structure at different spatial scales

\begin{tabular}{|c|c|c|c|c|}
\hline Variable & $R^{2}$ & $F$ & $P$ & Variables with the highest influence \\
\hline \multicolumn{5}{|l|}{ Richness } \\
\hline Drainage basin & 0.38 & 7.38 & 0.000 & \multirow[t]{3}{*}{ Irradiance $(0.669)$} \\
\hline Open environment & 0.31 & 2.46 & 0.100 & \\
\hline Shaded environment & 0.30 & 2.18 & 0.132 & \\
\hline Mesohabitat pools & 0.39 & 3.52 & 0.039 & Irradiance $(0.780)$ \\
\hline Mesohabitat riffles & 0.60 & 8.01 & 0.001 & $\begin{array}{l}\text { Current velocity }(-0.510) \\
\text { Irradiance }(0.476)\end{array}$ \\
\hline \multicolumn{5}{|l|}{ Abundance } \\
\hline Drainage basin & 0.28 & 4.55 & 0.008 & \multirow[t]{5}{*}{ Irradiance $(0.422)$} \\
\hline Open environment & 0.32 & 2.59 & 0.088 & \\
\hline Shaded environment & 0.06 & 0.36 & 0.780 & \\
\hline Mesohabitat pools & 0.13 & 0.82 & 0.497 & \\
\hline Mesohabitat riffles & 0.62 & 8.85 & 0.001 & \\
\hline \multicolumn{5}{|l|}{$H^{\prime}$} \\
\hline Drainage basin & 0.15 & 2.14 & 0.111 & \\
\hline Open environment & 0.05 & 0.28 & 0.834 & \\
\hline Shaded environment & 0.37 & 3.01 & 0.062 & \\
\hline Mesohabitat pools & 0.24 & 1.68 & 0.209 & \\
\hline Mesohabitat riffles & 0.58 & 7.40 & 0.002 & Current velocity $(-0.610)$ \\
\hline \multicolumn{5}{|l|}{ Dominance $(C)$} \\
\hline Drainage basin & 0.19 & 2.77 & 0.056 & \\
\hline Open environment & 0.09 & 0.536 & 0.664 & \\
\hline Shaded environment & 0.36 & 2.91 & 0.068 & \\
\hline Mesohabitat pools & 0.12 & 0.74 & 0.539 & \\
\hline Mesohabitat riffles & 0.60 & 8.19 & 0.001 & Current velocity (0.597) \\
\hline \multicolumn{5}{|l|}{ Equity $(J)$} \\
\hline Drainage basin & 0.17 & 2.41 & 0.082 & \\
\hline Open environment & 0.07 & 0.456 & 0.716 & \\
\hline Shaded environment & 0.37 & 2.96 & 0.065 & \\
\hline Mesohabitat pools & 0.19 & 1.31 & 0.303 & \\
\hline Mesohabitat riffles & 0.65 & 10.05 & 0.000 & Current velocity $(-0.620)$ \\
\hline
\end{tabular}

Values in bold represent statistically significant differences question: what features or particular characteristics favor the growth of a species or group of species in a particular region and not in another region located nearby and under the same environmental conditions? Borges and Necchi (2006) consider that competition for space, and thus the availability of a wider range of substrate types, explains the spatial distribution of macroalgae in lotic environments. Therefore, a high variety of substrate types and consequently different niches would favor the colonization of a greater number of species. However, our results demonstrate that each segment has a wide range of conditions including a substrate with multiple microhabitats under specific conditions readily established for the development of different microalgal species. This was not observed though, and each segment was occupied by only one or a few species and always with low levels of abundance.
Downes et al. (1998) believe that richness and species density can be regulated at the substrate level, like a rock in a stream, and that this regulation may be related to the structure of this habitat. Thus, the abundance of different physical elements, as well as fissures would be responsible for the increased complexity of the habitat (Downes et al. 1998; McCoy and Bell 1991). The provision of these different habitat resources affects the diversity and abundance of this biota. This postulate is valid for small microorganisms, as well as microscopic algae periphyton, for those edges and crevices occurring in a substrate may represent "mountains and valleys" during the development of the community (Murdock and Dodds 2007). However, for benthic macroalgae, which is the object of this study, such perception in microscale may go unnoticed (Kawata and Agawa 1999), playing a minor role in the development of 
these communities, unless we consider initial colonization processes.

Considering the microenvironmental conditions, the factors that impact the spatial distribution of macroalgae were irradiance and current velocity. Irradiance had a greater influence on the scales of drainage basin and mesohabitat pools to species richness and in the scale of drainage basin for species abundance. Relationships were observed for all variables associated to community structure in mesohabitat riffles. The negative relationship between current velocity and species richness, $H^{\prime}$, and equity, and positive relationship with dominance indicate that in this study, although velocity is essential to the development of macroalgal communities, it had a negative influence on the structure of communities, when too high. The positive influence of irradiance on the richness and the abundance of species showed that the growth of macroalgae in riffles (both in abundance and richness of species) still depends on the lower or greater availability of sunlight. Thus, the shading and microenvironmental variables (irradiance and current velocity) can be considered environmental variables that most affect the distribution of macroalgal benthic communities.

Acknowledgments The authors are immensely thankful to CNPQ for the doctorate scholarship (141388/2006-4) granted to the first author, and to the PRPPG Unespar for financial support.

\section{References}

Anagnostidis K, Komárek J (1988) Modern approach to the classification system of cyanophytes, 3-Oscillatoriales. Arch Hydrobiol 80/Algol Stud 50-53:327-472

Biggs BJF (1990) Periphyton communities and their environments in New Zealand rivers. N Z J Mar Freshw Res 24:367-386

Biggs BJF, Close ME (1989) Periphyton biomass dynamics in gravel bed rivers: the relative effects of flows and nutrients. Freshw Biol 22:209-223

Biggs BFJ, Gerbeaux P (1993) Periphyton development in relation to macro-scale (geology) and micro-scale (velocity) limiters in two gravel-bed rivers, New Zealand. $\mathrm{N}$ Z J Mar Freshw Res 27:39-53

Biggs BJF, Smith RA (2002) Taxonomic richness of stream benthic algae: effects of flood disturbance and nutrients. Limnol Oceanogr 47:1175-1186

Borges FR, Necchi O Jr (2006) Patterns of spatial distribution in macroalgal communities from tropical lotic ecosystems. Revista Brasileira de Botânica 29:669-680

Branco CCZ, Necchi O Jr (1996) Distribution of stream macroalgae in the eastern atlantic rainforest of São Paulo State, southeastern Brazil. Hydrobiology 333:139-150

Branco CCZ, Necchi O Jr (1998) Microhabitat and morphometric variation of two Chaetophoracean (Chaetophorales, Chlorophyta) species in tropical streams of southeastern Brazil. Phycol Res 46:169-174

Branco CCZ, Krupek RA, Peres CK (2009) Ecological distribution of stream macroalgal communities from mid-western region of Paraná State. Braz Arch Biol Technol 52:379-386
Cardinale BJ, Palmer MA, Swan CM, Brooks S, Poff NL (2002) The influence of substrate heterogeneity on biofilm metabolism in a stream ecosystem. Ecology 83:412-422

Cooper SD, Barmuta L, Sarnelle O, Kratz K, Diehl S (1997) Quantifying spatial heterogeneity in streams. J North Am Benthol Soc 16:174-188

Cooper SD, Diehl S, Kratz K, Sarnelle O (1998) Implications of scale for patterns and processes in stream ecology. Aust $\mathrm{J}$ Ecol 23:27-40

DeNicola DM, Hogland KD, Roemer SC (1992) Influence of canopy cover on spectral irradiance and periphyton assemblages in a prairie stream. J North Am Benthol Soc 11:391-404

Downes BJ, Lake PS, Schreiber SG, Glaister A (1998) Habitat structure and regulation of local species diversity in a stony, upland stream. Ecol Monogr 68:237-257

Entwisle TJ (1990) Macroalgae in the upper Yarra and Watts River catchments: distribution and Phenology. Aust J Mar Freshw Res 41:505-522

Gao Q, Yu M, Yang X (2000) A simulation analysis of the relationship between regional primary production and vegetation structure under climatic change scenarios. Ecol Model 131:33-45

Gordon ND, McMahon TA, Finlaylson BL (1992) Stream hydrology, an introduction for ecologists. Wiley, Chicheste

Gotelli NJ, Entsminger GL (2000) EcoSim: null models software for ecology. Version 5.0. Acquired Intelligence \& Kesey-Bear. http://homepages.together.net/ gentsmin/ecosim.htm

Kawata M, Agawa H (1999) Perceptual scales of spatial heterogeneity of periphyton for freshwater snails. Ecol Lett 2:210-214

Kohler SL, Wiley MJ (1997) Pathogen outbreaks reveal large-scale effects of competition in stream communities. Ecology 78:2164-2176

Komárek J, Anagnostidis K (1986) Modern approach to the classification system of cyanophytes, 2-Chroococcales. Arch Hydrobiol 73/Algol Stud 43:157-226

Komárek J, Anagnostidis K (1989) Modern approach to the classification system of Cyanophytes, 4-Nostocales. Arch Hydrobiol Suppl. 82/Algol Stud 56: 247-345

Krupek RA, Branco CCZ, Peres CK (2007) Distribuição ecológica das comunidades de macroalgas da bacia de drenagem do Rio das Pedras, região centro-sul do estado do Paraná, sul do Brasil. Revista Brasileira de Botânica 30:173-182

Lambert GA (1996) The role of periphyton in benthic food webs. In: Stevenson RJ, Bothwell ML, Lowe RL (eds) Algal ecology: freshwater benthic ecosystems. Academic Press, San Diego, California, pp 533-572

Levin SA (1992) The problem of pattern and scale in ecology. Ecology 73:1943-1967

Li HW, Lambert GA, Pearsons TN, Tait CK, Li JL (1994) Cumulative effects of riparian disturbances along high desert trout streams of the John Day Basin, Oregon. Trans Am Fish Soc 123:627-640

Maack R (2002) Geografia Física do Estado do Paraná, 3rd edn. Imprensa Oficial, Curitiba

McAULIFE JR (1984) Competition for space, disturbance, and the structure of a benthic stream community. Ecology 65:894-908

McCoy ED, Bell SS (1991) Habitat structure: the evolution and diversification of a complex topic. In: Bell SS, McCoy ED, Mushinsky HR (eds) Habitat structure: the physical arrangement of objects in space. Chapman and Hall, London

McCune B, Mefford MJ (1999) PC-ORD-multivariate analysis of ecological data, Version 4. MjM Software Design, Gleneden Beach

Meyer L (1997) Stream health: incorporating the human dimension to advance stream ecology. J North Am Benthol Soc 16:439-447 
Murdock JN, Dodds WK (2007) Linking benthic algal biomass to stream substratum topography. J Phycol 43:449-460

Necchi O Jr, Dip MR, Góes RM (1991) Macroalgae of a stream in southeastern Brazil: composition, seasonal variation and relation to physical and chemical variables. Hydrobiologia 213:241-250

Necchi O Jr, Pascoaloto D, Branco LHZ (1994) Distribution of macroalgae in a tropical river basin from southeastern Brazil. Archiv für Hydrobiologie 129:459-471

Necchi O Jr, Branco CCZ, Simões RCG, Branco LHZ (1995) Distribution of stream macroalgae in northwest region of São Paulo State, southeastern Brazil. Hydrobiologia 299:219-230

Necchi O Jr, Branco CCZ, Branco LHZ (2000) Distribution of stream macroalgae in São Paulo State, southeastern Brazil. Algol Stud 97:43-57

Pierce LL, Running SW (1995) The effects of aggregating subgrid land surface variation on large-scale estimates of net primary production. Landsc Ecol 10:239-253

Resh VH, Brown AV, Covich AP, Gurty ME, Li HW, Minshall GW, Reice SR, Sheldon AL, Wallace JB, Wissmar RC (1998) The role of disturbance in stream ecology. J North Am Benthol Soc 7:433-455
Sheath RG, Morinson MO, Korch JE, Kaczmarezyk D, Cole KM (1986) Distribuition of stream macroalgae in south-central Alasca. Hydrobiologia 135:259-269

Sheath RG, Hamilton PB, Hambrook JA, Cole KM (1989) Stream macroalgae of eastern boreal forest region of North America. Can J Bot 67:3553-3562

Sherwood AR, Kido MH (2002) Watershed-Scale comparations of algal biodiversity in high-quality proximate Hawaiian stream ecosystems. Pac Sci 56:431-440

Townsend CR, Hildrew AG, Francis JE (1983) Community structure in some southern English streams: the influence of physicochemical factors. Freshw Biol 13:521-544

Van De Hoek C, Mann DG, Jahns HM (1995) Algae. An introduction to phycology. Cambridge University Press, Cambridge

Wiley MJ, Kohler SL, Seelbach PW (1997) Reconciling landscape and local views of aquatic communities: lessons from Michigan trout streams. Freshw Biol 37:133-148

Zar JH (1999) Biostatistical analysis, 4th edn. Prentice Hall Inc, New Jersey, p 663 